Acta Horticulturae et Regiotecturae - Special Issue

Nitra, Slovaca Universitas Agriculturae Nitriae, 2021, pp. 50-57

\title{
CLIMATE CHANGE AND ITS IMPACT ON AGRICULTURE
}

\author{
Adrián VARGA \\ Institute of Hydrology SAS, Bratislava, Slovak Republic
}

\begin{abstract}
We live in the times of climate change when global temperatures are constantly rising. The impacts of climate change will also be felt in agriculture in Slovakia: increased productivity and yields in colder areas, reduced production in warmer areas due to temperature stress, risk of erosion as a result of more extreme weather conditions (stronger winds, more intense precipitation), the occurrence of new pests etc. Hence, we should be prepared for adaptation measures that would help mitigate it. The aim of this paper is to present the impacts of climate change on agriculture and land, and to offer adaptation measures, and show the prognosis of the climate indicator $T s>10^{\circ} \mathrm{C}$ from now until 2100 .
\end{abstract}

Keywords: climate change, impacts, adaptation, $T s>10^{\circ} \mathrm{C}$

Climate is, in simplified terms, a characteristic weather regime in a given area. For several meteorological elements (temperature, atmospheric precipitation, air pressure, air flow, wind direction and speed, snow cover, etc.), their statistical characteristics are evaluated (averages, extreme temperatures, daily and annual runs, variability, number of days, etc.) over a longer period, usually at least 30 years. Climate variability, i.e. long-term characteristics, is important just as weather variability (Metelka and Tolasz, 2009).

Climate change - this term has been used in the past for all climate-related changes, currently according to the UN

Intergovernmental Panel on Climate Change (IPCC, 1996), this is only a natural climate change, so it comprises altered solar activity and other astronomical factors, volcanic eruptions, changes in ocean circulation, etc. Climate change is only the part of all climate change caused by men by changing the greenhouse effect of the atmosphere (emissions of greenhouse gases and aerosols, changes in land use) (Lapin, 2014).

In recent years, our farmers have also been bothered by weather fluctuations during the growing season, heavy torrential rains, storms, and hail, or, conversely, the lack of rainfall, which reduces yields per hectare and the quality of crops. We know that climate change can have a major impact on human life, so it is particularly important to know its likely effect in terms of both quality and quantity. The subject of research is mainly climate change, i.e. only the part of all climate change that was conditioned by man's activities. Climate change, which is also expected to change the current nature of the flow in the atmosphere over the area, may significantly affect the typical nature of climatic conditions in our territory and subsequently significantly affect the agricultural sector. It was found that the onset of the growing season is accelerating, and the end is delayed compared to the last assessed climate standard 1961-1990 (Polák, 2018).

\section{Material and method}

\section{Climate change scenarios}

Although we know that global warming is happening today and is already affecting human society, its greatest consequences are in the future. Climate change is driven by several societal factors in the coming decades and centuries. The future development of most of these factors is deeply uncertain and will be influenced by our actions. It is therefore useless to ask, "What will happen?" and try to predict further climate change. The future, while inherently uncertain, is not entirely unknowable. Scenarios can be used to examine "What can happen?" and even "What should happen?", given the fact that we have been shaping our future. It is not about predicting the future, but about projecting what can happen by creating credible, coherent, and internally consistent descriptions of possible future climate change (Kriegler et al., 2020).

In general, seven different types of scenarios can be identified (Kriegler et al., 2020):

- Socio-economic scenarios that describe the development of social factors of human intervention in the climate system. Climate change and socio-economic development are deeply linked. Social and economic activities are major drivers of climate change. Climate change will have a serious impact on these activities, for example, by rising sea levels and exposing them to adverse weather events.

- Emission, concentration and climate scenarios resulting from these developments.

- Climate change scenarios resulting from human impact on the climate

- Climate impact scenarios due to these climate changes.

Contact address: Adrián Varga, Institute of Hydrology SAS, Dúbravská cesta č. 9, 84104 Bratislava, Slovak Republic; e-mail:varga@uh.savba.sk 


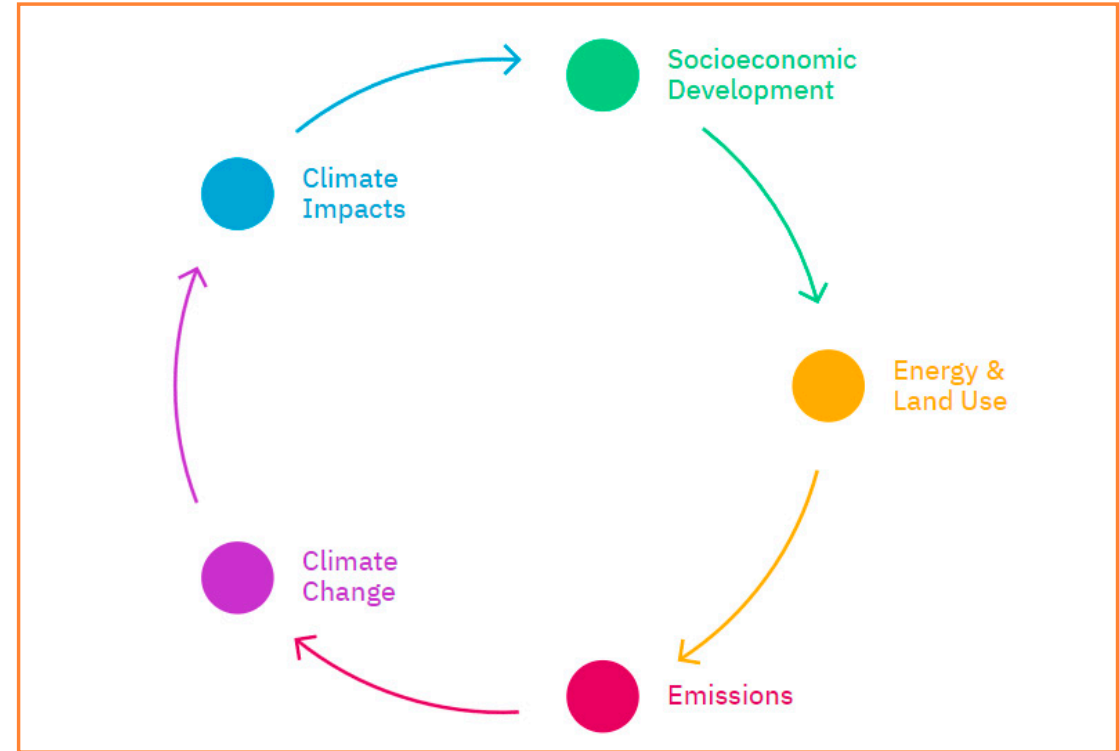

Figure 1 Mutual socio-economic and climate relations Source: Kriegler et al., 2020

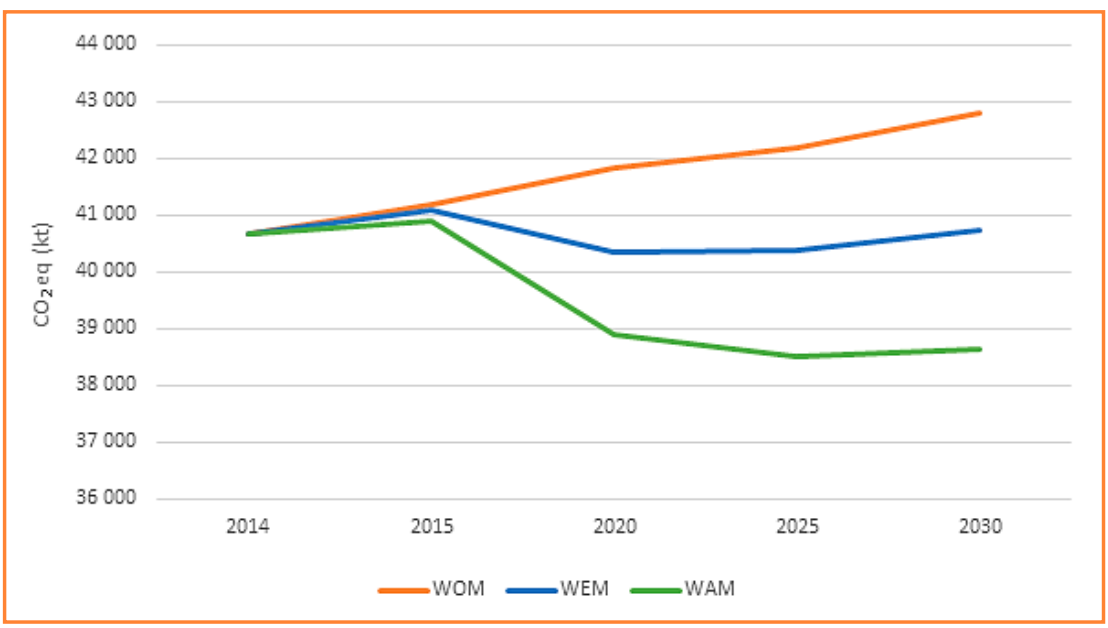

Figure 2 Greenhouse gases emissions projection by WOM, WEM and WAM scenarios Source: Enviroportal, 2016

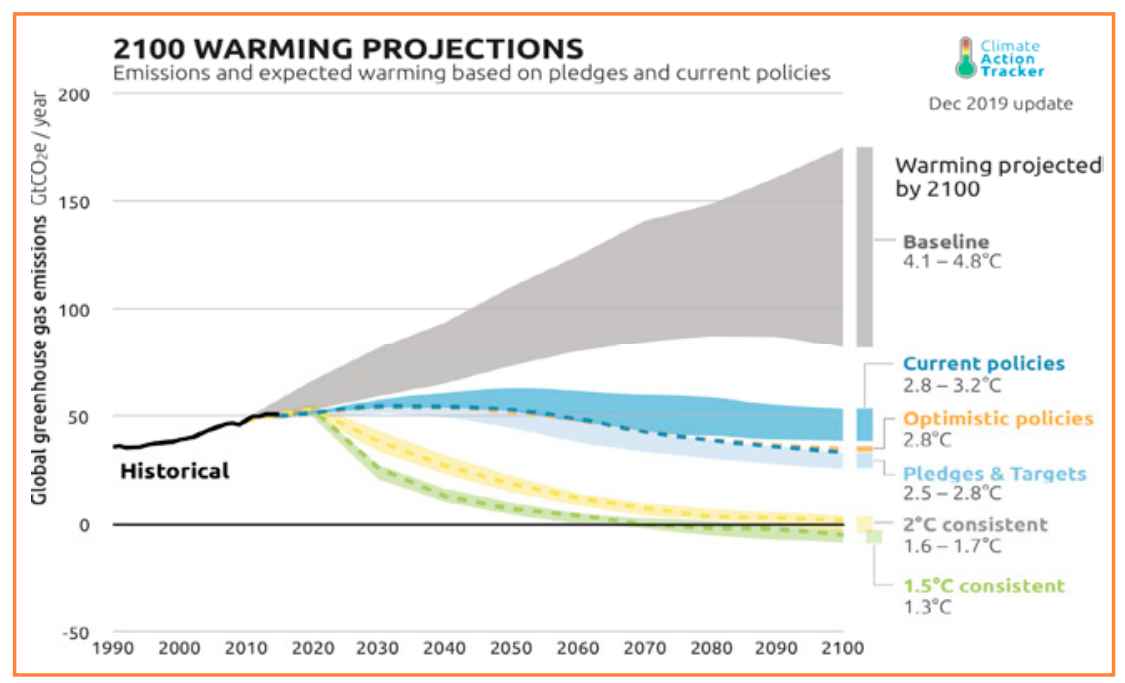

Figure 3 Global warming scenarios based on commitments and current policy Source: Climateactiontracker.org, 2020
- Mitigating scenarios that limit man-made climate change.

- Adaptation scenarios that limit the impact of climate change on societies.

- Integrated scenarios that capture some of the above components of future climate change.

Take a closer look at the Figure 1. to understand the underlying relationships. Since it is us, humans, who drive climate change, we can also act to reduce the impact of our activities on the climate (mitigation) as well as the impact of climate change on us (adaptation) (Kriegler et al., 2020).

\section{Greenhouse gases emissions projection in Slovakia}

Emission projections were prepared based on the 2014 emission inventory, in three scenarios: a no-action scenario (WOM), an existing measures scenario (WEM) and an added measures scenario (WAM) (Figure 2). The effect of the monitored measures is manifested mainly until 2020, measures of a medium-term nature until 2030 are poorly quantified, which is also reflected in the results until 2030 (Enviroportal.sk, 2016).

In the absence of policies (Figure 3), global warming is expected to reach $4.1{ }^{\circ} \mathrm{C}$ to $4.8{ }^{\circ} \mathrm{C}$ by the end of the century. The emissions that cause this warming are often called baseline scenarios, in the A scenario of "optimistic policies", that considers other as well as planned but not yet implemented policies and the continuation of recent developments. Given the optimistic assumption that governments will continue to meet these expectations, the average warming estimate is $2.8{ }^{\circ} \mathrm{C}$ or likely below $3.0{ }^{\circ} \mathrm{C}$. Scenario in line with current policy is 2.8 to $3.2^{\circ} \mathrm{C}$. Scenario in line with targets and commitments is 2.5 to $2.8^{\circ} \mathrm{C}$ Consistent scenarios for rapid reduction of global $\mathrm{CO}_{2}$ emissions, estimated warming from $1,3{ }^{\circ} \mathrm{C}$ to $2{ }^{\circ} \mathrm{C}$ by 2100 (Climateactiontracker.org, 2020).

\section{Greenhouse gases emissions}

\section{A. $\mathrm{CO}_{2}$ - Carbon dioxide}

Carbon dioxide $\left(\mathrm{CO}_{2}\right)$ is a colourless, tasteless, and odourless gas that is a common part of the Earth's atmosphere (0.04\%). The most 
important anthropogenic sources of carbon include any combustion of carbonaceous substances (from transport, industry, to domestic heating) and its leakage from the products in which it is contained. In the atmosphere, carbon dioxide absorbs infrared radiation and thus contributes to the so-called Greenhouse effect. Normal concentrations of carbon dioxide are harmless, short-term exposure to higher doses can cause headaches, dizziness, breathing difficulties, tremors, confusion, and ringing in the ears. Higher exposure can then cause convulsions, coma, and death (Kleger, Válek, 2014).

$\mathrm{CO}_{2}$ emissions for Slovakia (Figure 4) and major economies emissions (Figure 6).

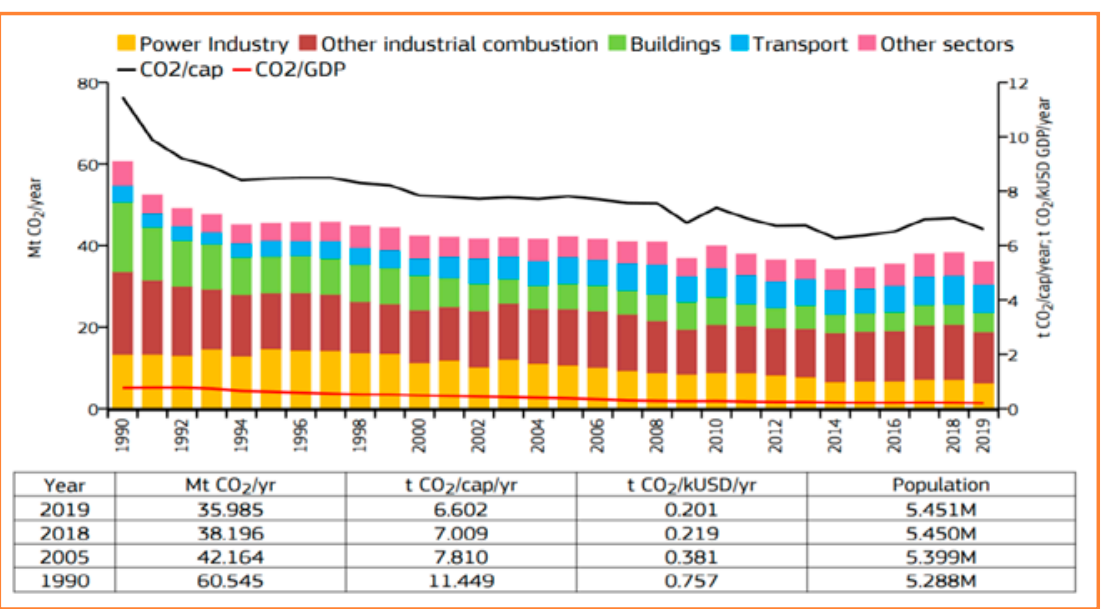

Figure $4 \mathrm{CO}_{2}$ emissions by sector for Slovakia Source: Crippa et al., 2020

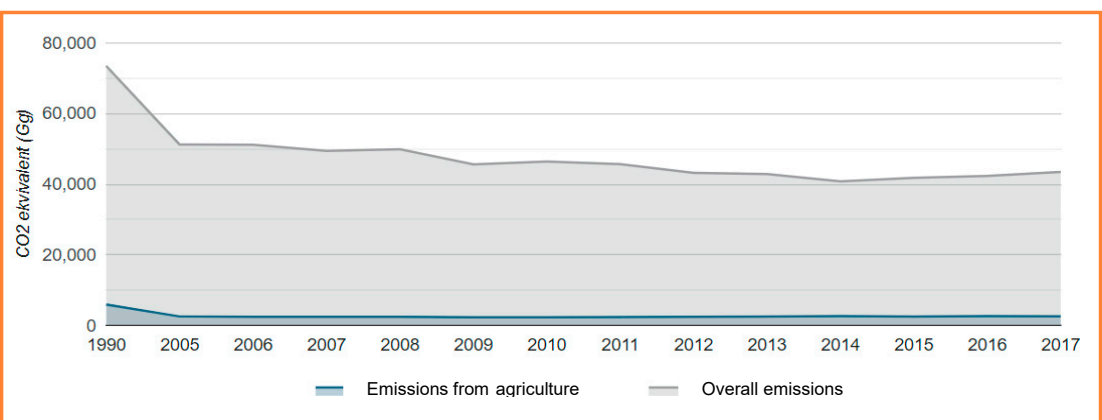

Figure $5 \quad \mathrm{CO}_{2}$ emissions from agriculture and overall emissions in Slovakia Source: Enviroportal.sk, 2020

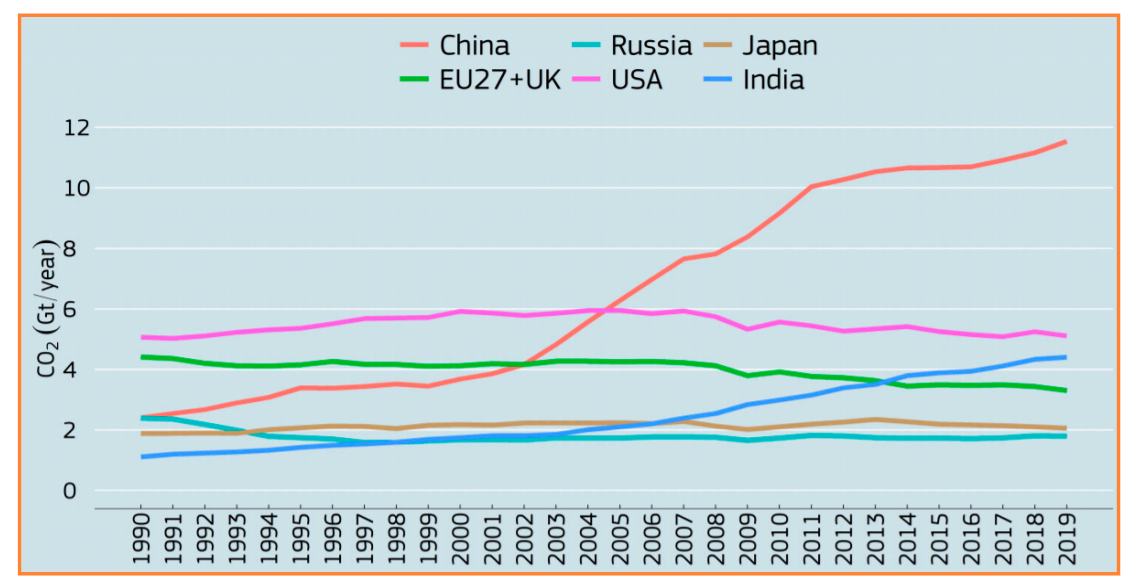

Figure 6 Fossil $\mathrm{CO}_{2}$ emissions of the major emitting economies Source: Crippa et al., 2020
Greenhouse gas emissions from agriculture have seen a declining trend since 1990, mainly due to a reduction in the number of livestock and the amount of industrial fertilizers used (Figure 5) (Enviroportal.sk, 2020).

\section{B. Nitrous oxide $\left(\mathrm{N}_{2} \mathrm{O}\right)$}

It is the third most important greenhouse gas according to the Kyoto Protocol. It is characterized by the production and use of mineral fertilizers, in the chemical industry, in agriculture, etc. It represents about $6 \%$ of global warming (Luna-anapa.ru, 2019).

The main source of nitrous oxide $\left(\mathrm{N}_{2} \mathrm{O}\right)$ is crop production - excess mineral nitrogen in the soil (due to intensive fertilization) and the unfavourable air regime of soils (soil compaction). The production of nitrous oxide from agriculture has had a fluctuating course after 2005 (Figure 7). In 2017, $4.66 \mathrm{Gg}$ of nitrous oxide was produced from agriculture (Enviroportal.sk, 2020).

\section{C. $\mathrm{CH}_{4}$ - methane}

Of all the greenhouse gases, methane is one of the most efficient due to its ability to efficiently absorb heat in the Earth's atmosphere. Studies have shown that over a 20-year period, a kilogram of methane heats the planet up to 80 times more than a kilogram of carbon dioxide. Methane lasts for about ten years in the Earth's atmosphere until it begins to react with free radicals called hydroxyl and is converted to carbon dioxide. Therefore, most of the methane time in the atmosphere is spent as a molecule of $\mathrm{CO}_{2}$. Methane is released much less into the air than carbon dioxide. Nevertheless, methane has lasting consequences. For example, one of these effects is a phenomenon called thermal expansion. Greenhouse gases such as methane heat the atmosphere and up to $90 \%$ of this excess heat is absorbed by the oceans. This heat causes the volume of seawater to expand. This effect, together with the melting of glaciers, causes an increase in sea levels (Leman, 2020).

The largest producers of methane $\left(\mathrm{CH}_{4}\right)$ include animal production-large cattle and pig farms. $\mathrm{CH}_{4}$ is formed as a direct product of metabolism in herbivores (enteric fermentation) and 


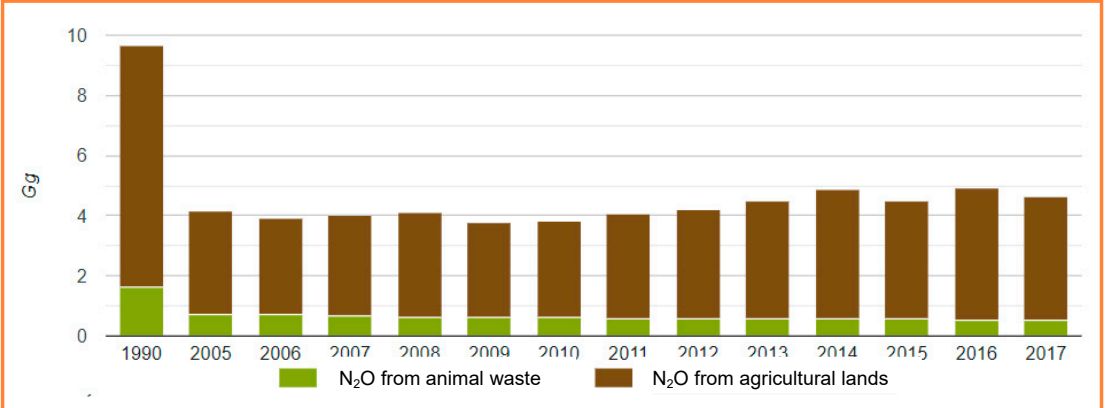

Figure 7 Nitrous oxide emissions agriculture in Slovakia Source: Enviroportal.sk, 2020

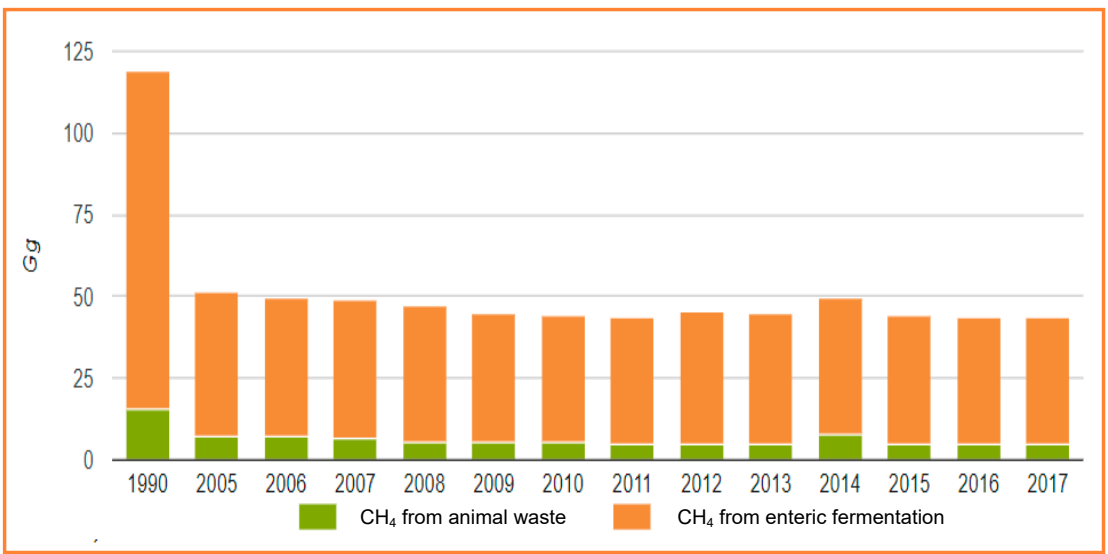

Figure 8 Methane emissions from agriculture in Slovakia Source: Enviroportal.sk, 2020

as a product of degradation of animal excrement. The share of agriculture in total methane production has been mostly decreasing since 2005 (Figure 8). In 2017, $43.44 \mathrm{Gg}$ (gigagram) of methane was produced from agriculture (Enviroportal.sk, 2020).

\section{Climate change impacts}

Climate change, in which the change in the current nature of the current in the atmosphere over a given area is to change, may also have a more significant effect on the typical nature of climatic conditions in our territory and consequently, significantly affect the agricultural sector. It was found that the onset of the growing season is accelerating and ends late compared to the last evaluated climatic standards 1961-1990. Long growing seasons significantly affect the possibilities of agriculture in growing more thermophilic crops, they also affect the total amount (input) of photosynthetically active radiation. It was found that in the case of climate conditions at $2 \times \mathrm{CO}_{2}$ during the large growing season (VVO) in the Danube lowlands, VVO (with frequent torrential rains and storms with intense hail in our territory, which can also damage the crops. Drought is becoming a big problem. The long rainless periods in our territory deplete the vegetation, but also the soil. Therefore, water needs to be brought to plants and their proper growth and development ensured, including by restoring irrigation systems in our fields, or focusing on growing plants that can withstand the stress of water scarcity more. Climate change can affect all spheres of society. Therefore, as stated in the final report on the Consequences of Climate Change and possible adaptation measures in individual sectors, it is necessary for society to prepare for the consequences of climate change not only in agriculture and forestry, and water management, but also in energy, transport, finance or health care as soon as possible (Polák, 2018).

\section{Adaptation measures}

\section{Adaptation measures in plant} production

The issue of coping with the consequences of climate change is one of the most serious global problems today. This is an issue that is not shortterm or easy to solve. It requires the cooperation of experts from many scientific disciplines and sufficient funding. From a factual point of view, it will generally be primarily the solution and implementation of projects in agriculture aimed at (Takáč, Zuzula, 2000):

1. application of protective and conservation technologies of tillage,

2. changes in crop technology,

3. changes in agroclimatic zoning and structure of cultivated crops and varieties,

4. changes in breeding programs,

5. changes in integrated crop protection,

6. changes in the regulation of the soil water regime,

7. changes in plant nutrition,

8. reduction of greenhouse gas emissions, processing of excrement and waste in animal production,

9. changes in the management of agricultural production,

10. revitalization of existing and construction of new irrigation facilities. 


\section{Change of cultivated crops}

Such a radical step will be possible in regions with higher altitudes, where thermal comfort is increased by growing crops, which are today different from the warmest regions of Slovakia. There is also a need to redesign crop technologies with an emphasis on sustainable farming systems, so that the natural fertility of the soil is maintained without degrading the environment (Takáč, Zuzula, 2000).

\section{Crop variety change}

Cultivated varieties should be adaptable to biotic and abiotic stresses. They should be less sensitive to temperature extremes, drought, and disease. The choice of a suitable variety will have to consider changing wintering conditions as well as ripening conditions. Better use of radiation power during the growing season can also be achieved by selecting varieties with a longer growing season (Takáč, Zuzula, 2000).

\section{Shift of the seeding date}

The onset of spring is likely to be very rapid compared to today's conditions. Maintaining current sowing dates could carry the risk of high temperatures during sensitive phenophases. The postponement of the sowing date to an earlier date is associated with the risk of reduced radiation energy input (Takáč, Zuzula, 2000).

\section{Irrigation systems}

The expected changes in the hydrological balance and in the hydrological cycle will result in an increased irrigation need. Supplemental irrigation is considered to be an effective way to alleviate or eliminate water stress of crops, and is still a necessary condition for optimizing the water regime of the soil for the needs of agricultural production in the southern regions of Slovakia (Takáč, Zuzula, 2000).

\section{Soil adaptation measures}

It is desirable to reduce interventions in the soil and optimize the dates of application of individual operations. To increase the content of soil organic matter, the effect of organic fertilization and incorporation of plant residues is considered to be a positive effect. It is recommended to increase the share of fodder on arable land and cover the vegetation in the winter months, which is an effective measure against erosion. Other protection measures include ploughing protection systems and crop rotation (Takáč, Zuzula, 2000).

\section{Methodology}

Data from meteorological stations were processed in spreadsheet software, the prognosis was calculated using the trend curve from previous known data (Figure 9). The formula used for calculation of the prognosis data:

$$
f(x)=11.6912779974 x+2,715.9628282828
$$

\section{Substitute column number for $x$. (1)}

From these values, map outputs were created using the interpolation method Kriging (raster pixel resolution 50) in ArcGIS software. Theoretical knowledge was obtained by researching available resources.

\section{Results and discussion}

Data overview is based on the existing measurements (1970, $2000)$ and prognosis $(2050,2100)$ of the used meteorological stations (Table 1). The calculation method is specified in the methodology.

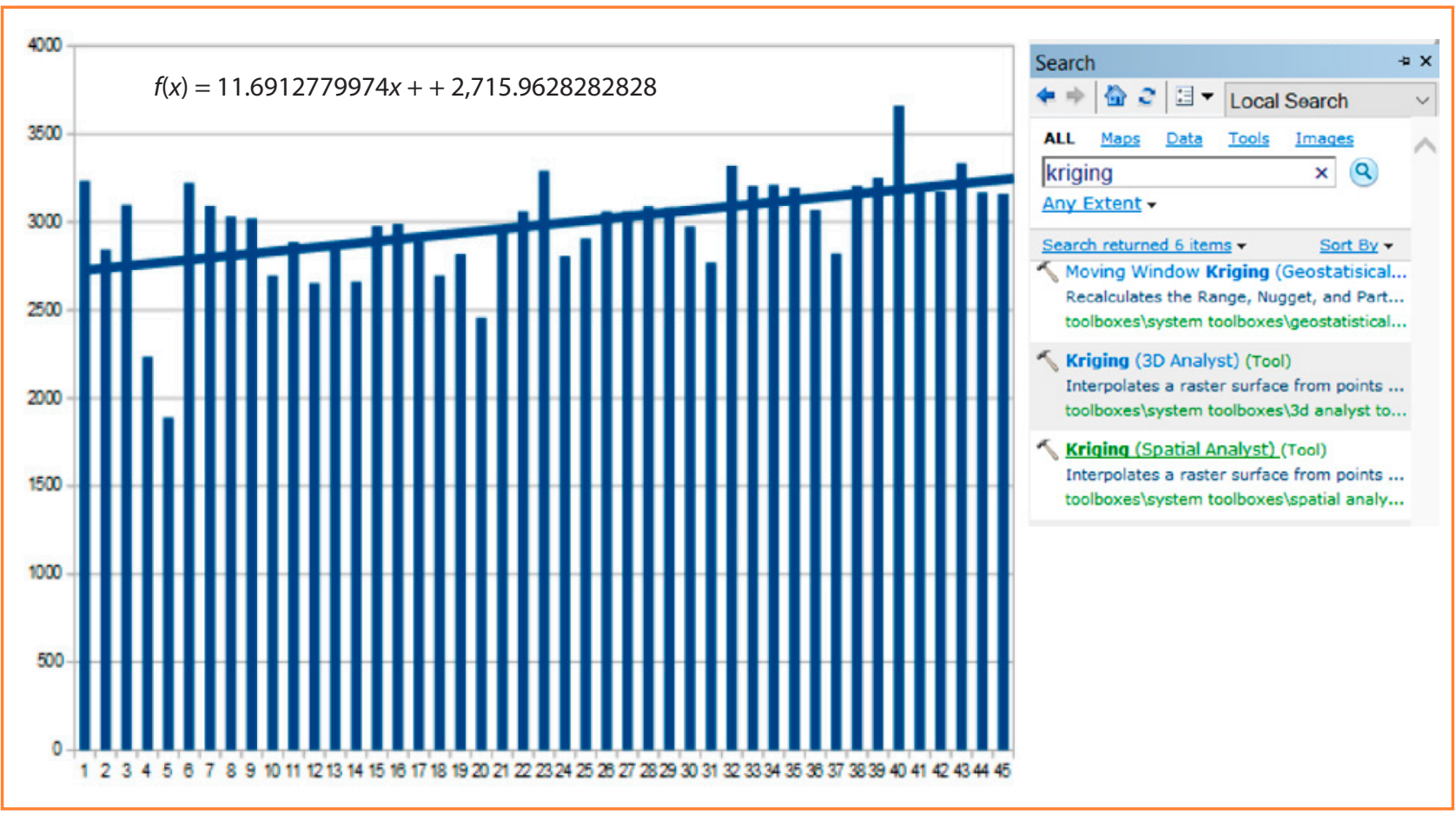

Figure 9 Prognosis metodology for $T s>10^{\circ} \mathrm{C}$ Source: Author 
Table $1 \quad T s>10^{\circ} \mathrm{C}$ sum values of used meteorological stations in Slovakia

\begin{tabular}{|c|c|c|c|c|}
\hline$\downarrow$ station/year $\rightarrow$ & 1970 & 2000 & 2050 & 2100 \\
\hline Holíč & $2,695.8$ & $3,662.7$ & $3,768.2$ & $4,352.7$ \\
\hline Kuchyňa, air base Malacky & $2,706.4$ & $3,640.4$ & $3,571.1$ & $3,989.2$ \\
\hline Biskupice, at the airport Trenčín & $2,564.5$ & $3,554.7$ & $3,360.0$ & $3,701.1$ \\
\hline Malacky & $2,819.0$ & $3,704.6$ & $3,616.5$ & $4,013.0$ \\
\hline Senica & $2,610.4$ & $3,589.1$ & $3,439.3$ & $3,807.2$ \\
\hline Myjava & 2,319.6 & $3,239.9$ & $3,322.2$ & $3,880.0$ \\
\hline Bratislava, Karlova Ves & $2,848.5$ & $3,711.9$ & $3,621.9$ & $4,018.2$ \\
\hline Jurske jazero, Borinka pri BA & $2,169.9$ & $3,076.0$ & $2,963.5$ & $3,336.4$ \\
\hline Bratislava, Koliba & $2,646.9$ & $3,564.0$ & $3,512.8$ & $3,934.6$ \\
\hline Pezinok & $2,887.6$ & $3,722.4$ & $3,631.4$ & $4,021.9$ \\
\hline Bratislava, airport & $2,934.4$ & $3,352.3$ & $3,653.9$ & $4,041.9$ \\
\hline Král'ová pri Senci & $2,925.4$ & $3,785.1$ & $3,622.5$ & $3,981.5$ \\
\hline Gabčíkovo & $2,930.8$ & $3,391.4$ & $3,528.3$ & $3,820.3$ \\
\hline Jaslovské Bohunice, nuclear powerplant & $2,680.8$ & $3,599.7$ & $3,430.4$ & $3,758.9$ \\
\hline Žihárec & $2,906.5$ & $3,366.5$ & $3,531.4$ & $3,837.6$ \\
\hline Pieštany, airport & $2,679.0$ & $3,231.9$ & $3,371.0$ & $3,669.1$ \\
\hline Trenčianske Teplice & $2,397.2$ & $3,359.2$ & $3,151.5$ & $3,478.8$ \\
\hline Piesok & $2,245.0$ & $3,152.1$ & $3,048.7$ & $3,433.2$ \\
\hline Dolný Hričov, airport Žilina & $2,169.4$ & $3,059.2$ & $2,885.8$ & $3,208.5$ \\
\hline Velké Ripňany & $2,774.3$ & $3,642.6$ & $3,439.7$ & $3,740.7$ \\
\hline Krušovce & $2,773.6$ & $3,654.4$ & $3,481.4$ & $3,819.9$ \\
\hline Lovce & $2,587.5$ & $3,514.3$ & $3,325.9$ & $3,648.6$ \\
\hline Podhájska & $2,888.5$ & $3,772.9$ & $3,547.9$ & $3,872.2$ \\
\hline Nitra - Janíkovce, airport & $2,815.6$ & $3,718.0$ & $3,579.2$ & $3,945.7$ \\
\hline Hurbanovo & $2,917.3$ & $3,811.7$ & $3,584.5$ & $3,912.0$ \\
\hline Beluša & $2,323.6$ & $3,310.8$ & $3,117.5$ & $3,464.9$ \\
\hline Bystrička & $2,037.7$ & $2,932.8$ & $2,870.0$ & $3,271.4$ \\
\hline Žilina & $2,087.5$ & $2,995.9$ & $2,863.4$ & $3,214.3$ \\
\hline Čadca & $2,120.4$ & $2,839.8$ & $2,701.2$ & $3,001.1$ \\
\hline Oravská Lesná & $1,402.9$ & $1,802.9$ & $2,102.7$ & $2,448.8$ \\
\hline Rabča & $1,622.4$ & $2,740.2$ & $2,329.3$ & $2,636.2$ \\
\hline Ružomberok & $2,175.2$ & $3,012.0$ & $2,813.9$ & $3,111.6$ \\
\hline Liptovský Hrádok & $1,876.5$ & $2,677.6$ & $2,406.6$ & $2,614.5$ \\
\hline Liptovský Mikuláš - Liptovská Ondrašová & $1,976.7$ & $2,767.6$ & $2,524.8$ & $2,751.9$ \\
\hline Dudince & $2,832.3$ & $3,734.0$ & $3,480.8$ & $3,770.1$ \\
\hline Želiezovce & $2,888.0$ & $3,781.7$ & $3,591.6$ & $3,940.9$ \\
\hline Vieska nad Žitavou & $2,786.3$ & $3,702.4$ & $3,481.4$ & $3,801.0$ \\
\hline Oravské Veselé & $1,442.3$ & $1,866.7$ & $2,099.8$ & $2,400.9$ \\
\hline Oravský Podzámok & $1,929.3$ & $2,845.5$ & $2,705.8$ & $3,074.5$ \\
\hline Martin - Záturčie & $2,031.2$ & $2,906.0$ & $2,633.0$ & $2,913.5$ \\
\hline Turčianske Teplice & $2,437.7$ & $3,200.3$ & $2,928.5$ & $3,098.9$ \\
\hline Žiar nad Hronom & $1,940.3$ & $2,376.3$ & $2,377.3$ & $2,617.8$ \\
\hline
\end{tabular}


Continuation of table 1

\begin{tabular}{|c|c|c|c|c|}
\hline$\downarrow$ station/year $\rightarrow$ & 1970 & 2000 & 2050 & 2100 \\
\hline Bzovík & $2,353.3$ & $3,247.1$ & $3,164.3$ & $3,540.8$ \\
\hline Sielnica & $2,344.1$ & $3,199.7$ & $3,148.3$ & $3,536.8$ \\
\hline Víglaš - Pstruša & $2,325.0$ & $3,221.3$ & $3,156.9$ & $3,565.9$ \\
\hline Dolné Plachtince & $2,711.4$ & $3,500.5$ & $3,321.5$ & $3,605.0$ \\
\hline Liptovské Revúce & $1,933.4$ & $2,744.5$ & $2,660.0$ & $3,029.0$ \\
\hline Sihla - Drábsko & $1,463.1$ & $2,020.0$ & $2,093.0$ & $2,371.0$ \\
\hline Brezno & $2,241.0$ & $2,892.3$ & $2,836.9$ & $3,217.4$ \\
\hline Liesek & $1,562.0$ & $2,011.1$ & $2,267.5$ & $2,601.7$ \\
\hline Lučenec - airport, Bolkovce & $2,608.9$ & $3,409.2$ & $3,190.7$ & $3,400.4$ \\
\hline Poprad - airport & $1,814.0$ & $2,537.9$ & $2,227.5$ & $2,374.9$ \\
\hline Ratková & $2,417.6$ & $3,218.7$ & $3,001.3$ & $3,221.3$ \\
\hline Rimavská Sobota & $2,833.2$ & $3,415.8$ & $3,195.3$ & $3,417.6$ \\
\hline Rožňava & $2,381.3$ & $3,211.7$ & $2,999.9$ & $3,234.9$ \\
\hline Švedlár & $1,968.5$ & $2,896.9$ & $2,616.4$ & $2,878.4$ \\
\hline Štós & $1,939.6$ & $2,903.8$ & $2,599.9$ & $2,845.7$ \\
\hline Zlatá Idka & $2,567.9$ & $3,373.3$ & $3,171.3$ & $3,402.5$ \\
\hline Spišské Vlachy & $2,191.8$ & $2,978.0$ & $2,707.5$ & $2,903.3$ \\
\hline Podolínec & $1,761.4$ & $2,478.9$ & $2,298.8$ & $2,515.7$ \\
\hline Červený Kláštor - Pieninský národný park & $1,899.2$ & $2,702.2$ & $2,496.3$ & $2,746.0$ \\
\hline Gánovce - Filice & $1,746.0$ & $2,453.4$ & $2,166.8$ & $2,307.6$ \\
\hline Revúca & $2,356.1$ & $3,120.2$ & $2,882.0$ & $3,067.6$ \\
\hline Prešov - Nižná Šebastová & $2,260.0$ & $3,039.0$ & $2,907.8$ & $3,176.2$ \\
\hline Stará Lesná & $1,533.2$ & $1,875.8$ & $1,993.0$ & $2,160.7$ \\
\hline Plaveč & $1,915.0$ & $2,663.1$ & $2,532.5$ & $2,816.9$ \\
\hline Bardejov & $2,231.3$ & $2,963.8$ & $2,851.7$ & $3,124.8$ \\
\hline
\end{tabular}

Source: Author

Based on the results of our climate indicator $T s \geq 10{ }^{\circ} \mathrm{C}$, which defines the beginning and end of the main growing season (HVO) of plants, we can say with certainty that this period will be extended, because the results of our work show an increase in the value of $T s \geq 10^{\circ} \mathrm{C}$ in the forecast from now until 2100 to $800{ }^{\circ} \mathrm{C}$ (Figure 10). Similar results regarding the extension of HVO can be found e.g. in the work (Ďörd', Ložek, Hronský, 2010), where their results show for the years 20052008 the extension of HVO vineyards by an average of 12 days (earlier onset, later termination), due to increasing the amount of active temperatures. Furthermore, for example, in the report by VúPOP-Climate change and its possible impacts on the soil of Slovakia for 2005 (Sobocká, Šurina, Torma, Dodok, 2005), there are mentioned predictions for an increase in the amount of $T s \geq 10^{\circ} \mathrm{C}$ in 2075 in southern areas by $1,111^{\circ} \mathrm{C}$, to north by $802{ }^{\circ} \mathrm{C}$, our assumptions are lower, but we will agree that these values will increase Sar, Avcl, Avci (2019). They evaluated the vegetation period according to climate change scenarios (RCP 4.5 and RCP 8.5) in the Inner Western Anatolia sub-area. The growing season in this locality can increase by 15-20 days and 40 days, respectively. According to Olszewski and Żmudzka
(2000), the length of the growing season is extended by 1 to 3 days per decade. According to the Walthall et al. (2012), temperature changes varied by season as well as by region. The cooling of the south-eastern country has slowed down in recent decades. In most of the United States, the centuryold linear trend is dominated by autumn warming in the 1930s and 1940s, and therefore, long-term trends remain small, with the southwest exception. This total warming is reflected in the extension of the growing season in the northern hemisphere by approximately 4 to 16 days since 1970 (i.e. 1 to 4 days per decade).

\section{Conclusions}

In Slovakia, climate change will have an impact on the production of some crops, either negatively or in some cases positively. Value of climatic indicator $T s>10$ will increase by $800{ }^{\circ} \mathrm{C}$ in sum to the year 2100 . Based on the results, we can state that the duration of the main vegetation period in Slovakia will be extended. The data and findings in this paper can be used in further research into the effects of climate change. 

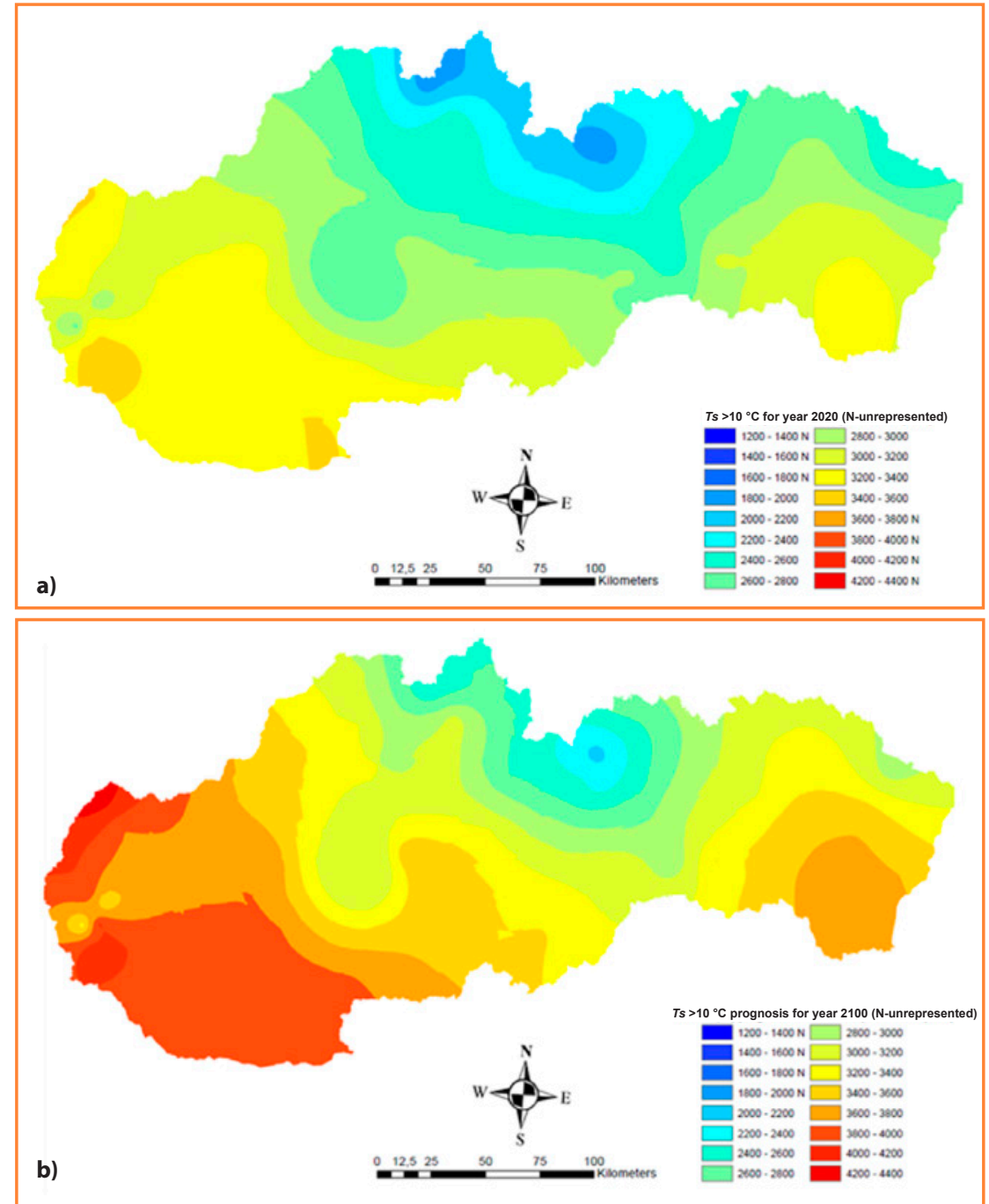

Figure 10 Prognosis $T s>10^{\circ} \mathrm{C}$ for years 2020 (a) and 2100 (b), divided into categories Source: Author

\section{Acknowledgment}

I would like to thank my former supervisor doc. Ing. Ján Čimo, PhD., as well as my current supervisor Ing. Yvetta Velísková, PhD. for professional guidance

This paper was created on the basis of my diploma thesis and also with the support from the project no. APVV-18-0205.

\section{References}

Climateactiontracker.org (1. 12. 2020). Temperatures-Adressing global warming. https://climateactiontracker.org/global/ temperatures/

Crippa, M., Oreggioni, G., Guizzardi, D., Muntean, M., Schaaf, E., Lo Vullo, E. et al. (2019). Fossil $\mathrm{CO}_{2}$ and $\mathrm{GHG}$ emissions of all world countries - 2019. Report JRC Publications Repository. https:// sk https://milanlapin.estranky.sk/clanky/ klimaticke-zmeny-strucne/

Leman, J. (25. 9. 2020). What Is Methane, Anyway? Popularmechanics.com https://www.popularmechanics.com/ science/environment/a28858699/ what-is-methane/

Luna-anapa.ru (2019). Zdroje skleníkových plynov $v$ atmosfére. Skleníkový plyn. Zdroje skleníkových plynov. https://kraskivam.ru/ sk/rossiya/istochniki-parnikovyh-gazov-vatmosfere-parnikovyi-gaz/

Metelka, L., Tolasz, R. (2009). Klimatické zmèny: fakta bez mýtů. web. archive.org, http://web.archive.org/ web/20120111082610/http://www.czp. cuni.cz/Knihovna/publikace/klimatickezmeny-web.pdf

Midriak, R., Zaušková, L. (2014). Krajina Slovenska a jej využívanie vo vzt’ahu ku klimatickej zmene. In Kobza, J. (ed.) Klimatická změna-zmierňujúce a adaptačné opatrenia $v$ sektore pôdohospodárstva. Slovenská akadémia pôdohospodárskych vied. Zborník 74, Nitra: Národné pol'nohospodárske centrum a potravinárske centrum (pp. 64-72).

Olszewski, K., Żmudzka, E. (2000). Variability of the Vegetative Period in Poland. Miscellanea Geographica, 9, 59-70. DOI: 10.2478/mgrsd-2000-090108

Polák, J. (24. 4. 2018). Klimatická zmena a jej možný vplyv na polnohospodárstvo Slovenska. Fapz.uniag.sk, https://fapz. uniag.sk/sk/aktualne-informaciereader/klimatick\%C3\%A1-zmena-ajej-mo\%C5\%BEn\%C3\%BD-vplyv-napo\%C4\%BEnohospod\%C $3 \% A 1$ rstvoslovenskal

Sar, T., Avcl, S., Avci, M. (2019). Evaluation of the vegetation period according to climate change scenarios: a case study in the inner west anatolia subregion of Turkey. Journal of Geography, 39, 29-39. DOI: 10.26650/ JGEOG2019-0018

Sobocká, J., Šurina, B., Torma, S., Dodok, R. (2005). Klimatická zmena ajej charakteristika. Klimatická zmena a jej možné dopady na pôdny fond Slovenska. Bratislava: Výskumný ústav pôdoznalectva a ochrany pôdy (46p.). Takáč, J., Zuzula, I. (2000). Adaptácia pôdohospodárstva v Slovenskej republike na klimatickú zmenu. Národný klimatický program SR. NKP 9/00. Bratislava: MŽP SR a SHMÚ (pp. 74-86).

Walthall, C. L. J., Hatfield, P., Backlund, L., Lengnick, E., Marshall, M., Walsh, S. et al. (2012). Climate Change and Agriculture in the United States: Effects and Adaptation. usda.gov. https://www.usda.gov/sites/ default/files/documents/CC\%20and\%20 Agriculture\%20Report\%20(02-04-2013) b.pdf Change Scenarios? Climatescenarios.org https://climatescenarios.org/primer

Lapin, M. (22. 9. 2014). Úvod do problematiky klimatických zmien. eStranky. 